\title{
THE EFFECT OF ENERGY INTAKE AND ICI 33828 ON OVULATION RATE IN SWINE*
}

\author{
R. B. STAIGMILlER, D. L. GARBERS AND N. L. FIRST \\ University of Wisconsin, Madison, Wisconsin 53707, U.S.A.
}

(Received 8th February 1972, accepted 13th March 1972)

Increasing the level of energy intake of gilts has been shown to increase ovulation rate, but the exact hormonal mechanism by which this phenomenon occurs is unknown. Different quantitative changes in the pituitary content of $\mathbf{L H}$ and FSH of gilts on high and low energy intakes were reported, however, by Kirkpatrick, Howland, First \& Casida (1967). They also noted a higher progesterone content of the corpora lutea from gilts on high energy than from those on low energy intake.

Methallibure (ICI 33828) inhibits the release of pituitary LH and FSH in swine (Garbers \& First, 1969). Gilts receiving the compound showed a lower level of luteal progesterone than control gilts on Day 8 but a higher level on Day 16 (Stormshak, Leverage, Kelley \& Gerrits, 1970).

The present study was conducted to determine if an increase in ovulation rate could be brought about by an increase in energy intake following the feeding of a hypothalamic inhibitory drug.

Sixty-one gilts were randomly assigned to one of four treatment groups (T) or one of three control groups $(\mathrm{C})$. At the start of the treatment period, two of the treated groups (TL) were fed basal ration $\mathrm{A}(1.4 \mathrm{~kg}=4911 \mathrm{kcal}) / \mathrm{gilt} / \mathrm{day}$, and the other two groups $(\mathrm{TH})$ were fed the high energy ration $(2 \cdot 8 \mathrm{~kg}=$ $10,000 \mathrm{kcal}$ ). The high energy ration consisted of $1.4 \mathrm{~kg}$ basal ration A plus $1.4 \mathrm{~kg}$ glucose. These rations provided $100 \mathrm{mg}$ ICI $33828 /$ gilt/day and were fed for 20 days. After the treatment period, ICI 33828 was discontinued, and half of the group on each ration was transferred to the other ration (TLH, THL) and half remained on their respective treatment rations (TLL, THH). This feeding scheme was followed until slaughter.

Rations offered to the three control groups were: Group 1, basal ration A until Day 15 of the cycle then high energy ration until slaughter (CLH); Group 2, basal ration A throughout the experiment $\left(\mathrm{CLL}_{\mathrm{A}}\right)$; Group 3, basal ration $B$ throughout the experiment $\left(C_{C L}\right)$. Basal ration $B$ had a different composition than basal ration $\mathrm{A}$ but was fed at a level isocaloric with it $(1.8 \mathrm{~kg}$ $=4960 \mathrm{kcal})$. Methallibure in high doses has been shown to decrease feed intake (Gerrits \& Johnson, 1965) but all treatment groups in this study consumed their full daily ration.

All gilts were checked daily with a vasectomized boar for the onset of heat and were slaughtered on Day 4 (day of oestrus = Day 1) following post-treatment oestrus. At slaughter, the ovulation rate for each gilt was determined by

* Paper No. 597 from the Department of Meat and Animal Science. 
count of the corpora lutea. Tests for significance differences in ovulation rates were made by predetermined orthogonal comparisons and Duncan's Multiple Range test.

One gilt in each of the groups THH, THL, CLL $_{B}$ and two gilts in CLL $_{A}$ had not ovulated at the time of slaughter and were not included in the analysis.

The mean ovulation rate for each of the seven groups is shown in Table 1. When they were transferred to a high energy ration for 7 days, the control gilts in this experiment (Group 3) showed an increased ovulation rate $(P \simeq 0.06)$ compared to gilts on a continuous low energy intake. Treated gilts failed to show

TABLE 1

MEAN OVULATION RATES IN GILTS FED ICI 33828 AND DIFFERENT LEVELS OF ENERGY

\begin{tabular}{l|cccc|ccc}
\hline & \multicolumn{4}{|c|}{ Treated } & \multicolumn{3}{|c}{ Controls } \\
\cline { 2 - 8 } & THH & $T L H$ & $T H L$ & $T L L$ & $C L H$ & $C L L_{A}$ & $C L L_{B}$ \\
\hline No. of corporal lutea & 3.4 & $10 \cdot 0$ & $8 \cdot 1$ & $9 \cdot 6$ & 13.5 & 11.5 & $11 \cdot 3$ \\
\hline
\end{tabular}

For abbreviations, see text.

TABLE 2

DUNCAN'S MULTIPLE RANGE TEST OF OVULATION RATES OF GILTS FED ICI 33828 AND DIFFERENT LEVELS OF ENERGY

\begin{tabular}{l|ccccc}
\hline & \multicolumn{5}{|c}{ Feed level } \\
\cline { 2 - 6 } & $T L L$ & $T L H$ & $C L L_{B}$ & $C L L_{A}$ & $C L H$ \\
\hline Mean ovulation rate* & 9.6 & 10.0 & 11.3 & 11.5 & 13.5 \\
\cline { 2 - 5 } & & & & & \\
\hline
\end{tabular}

For abbreviations, see text.

* All values not underscored by the same line are significantly different $(P<0 \cdot 05)$.

a similar increase $(P \simeq 0.35)$ even though the length of time during which the high energy level was fed has been shown to be sufficient to evoke an increase (Zimmerman, Spies, Self \& Casida, 1960). Within the treated groups, there was no significant difference in ovulation rate associated with energy level during or after treatment, or with an interaction between the periods during and after treatment.

A trend towards lowered ovulation rates in gilts fed ICI 33828 was reported by Stratman \& First (1969) and, in the present study, the treated gilts showed a lower ovulation rate $(P<0.01)$ than the controls. However, two of the treated groups (THL, THH) had no control groups with which they were contemporary so they were disregarded, and the five remaining groups were next examined by a multiple range test (Table 2). This test indicated a difference $(P<0.05)$ between the treated and control groups on the TLH or CLH 
feeding regimens but no difference between treated and controls on the TLL or CLL feeding regimens. These results can be explained on the basis of ICI 33828 inhibiting the mechanism by which energy intake increases ovulation rate.

The hormonal pattern of cyclic gilts is clearly altered by treatment with ICI 33828. Differences in pituitary levels of FSH and LH, follicular development in the ovary, and progesterone content in corpora lutea have all been shown between treated and non-treated gilts (Garbers \& First, 1969; Stormshak et al., 1970). Similar effects of ICI 33828 and progestational compounds on ovulation have been demonstrated utilizing stereotaxic cranial implantation techniques in guinea-pigs. Although they act at different loci within the hypothalamus and pituitary, both ICI 33828 and medroxyprogesterone acetate were effective in blocking ovulation (Malven, 1971; Malven \& Ruiz Diaz, 1971). Hence, it is reasonable to assume that the hypothalamic inhibitory drug ICI 33828 alters the hormonal pattern of treated gilts to the extent that the effects of high energy levels were unable to manifest themselves in the presence of the drug.

This research was supported by the College of Agricultural and Life Sciences, University of Wisconsin, Madison and also in part by Ayerst Laboratories, New York.

\section{REFERENCES}

Garbers, D. L. \& FIRST, N. L. (1969) The effects of injected oestradiol-17 $\beta$, progesterone and dietary ICI 33828 on ovarian and pituitary functions in the sow and gilt. 7 . Reprod. Fert. 20, 451.

GerRTts, R. J. \& Johnson, L. A. (1965) Synchronization of estrus in gilts fed two levels of I.C.I. 33828 and the effect on fertility, embryo survival and litter size. (Abstract). F. Anim. Sci. 24, 917.

Kirkpatrick, R. L., Howland, B. E., First, N. L. \& Casida, L. E. (1967) Ovarian and pituitary gland changes in gilts on two nutrient energy levels. 7. Anim. Sci. 26, 358.

Malven, P. V. (1971) Hypothalamic sites of action for methallibure (ICI 33828) inhibition of gonadotropin secretion. F. Anim. Sci. 32, 912.

Malven, P. V. \& Ruiz-Diaz, R. (1971) Inhibition of ovulation by intra-cranial implants of medroxyprogesterone acetate. F. Anim. Sci. 32, 919.

Stormshak, F., Leverage, W. E., JR, Kelley, H. E. \& Gerrits, R. J. (1970) Hypothalamo-hypophysial and ovarian characteristics of gilts fed methallibure. F. Anim. Sci. 30, 556.

Stratman, F. W. \& First, N. L. (1969) Diet consumption, bodyweight change, estrus inhibition, and reproductive performance in gilts fed a dithio-carbamoylhydrazine (ICI 33828). F. Anim. Sci. 28, 353.

Zimmerman, D. E., Spies, H. G., Self, H. L. \& CAsida, L. E. (1960) Ovulation rate in swine as affected by an increased energy intake just prior to ovulation. F. Anim. Sci. 19, 295. 